\title{
NOTE
}

\section{A model of carbon isotopic fractionation and active carbon uptake in phytoplankton}

\author{
Klaus Keller ${ }^{1, *}$, François M. M. Morel ${ }^{2}$ \\ 'Department of Civil Engineering and Operations Research and ${ }^{2}$ Department of Geosciences, Princeton University, Princeton, \\ New Jersey 08544, USA
}

\begin{abstract}
The carbon isotopic fractionation of phytoplankton photosynthesis $\left(\varepsilon_{\mathrm{p}}\right)$ has been interpreted by previous authors as inconsistent with active bicarbonate uptake. This interpretation contradicts the results of numerous physiological studies demonstrating significant active bicarbonate uptake in phytoplankton. Using a simple model of cellular regulation of carbon acquisition we show that an upward curvature of $\varepsilon_{\mathrm{p}}$ as a function of the ratio of growth rate to carbon dioxide concentration does not exclude active bicarbonate uptake. Our model describes adequately published carbon isotope data for cyanobacteria, diatoms, and coccolithophores consistent with active bicarbonate uptake.
\end{abstract}

KEY WORDS: Phytoplankton - Carbon isotopic fractionation . Model - Active carbon uptake - Bicarbonate Carbon dioxide

The carbon isotopic fractionation of phytoplankton photosynthesis $\left(\varepsilon_{p}\right)$ is an important biogeochemical signal used, for example, to estimate ancient carbon dioxide concentrations (e.g. Jasper \& Hayes 1990). Unfortunately, many observations contradict the existing $\varepsilon_{\mathrm{p}}$ models. Most $\varepsilon_{\mathrm{p}}$ models consider only diffusive carbon dioxide $\left(\mathrm{CO}_{2}\right)$ transport into the cell (e.g. Laws et al. 1995), which is inconsistent with laboratory and field data that demonstrate active uptake of $\mathrm{CO}_{2}$ and/or bicarbonate $\left(\mathrm{HCO}_{3}{ }^{-}\right)$(e.g. Sikes et al. 1980, Tortell et al 1997, for a review see Raven 1997). Further, these models predict a linear relationship between $\mu /\left[\mathrm{CO}_{2}\right]$ (the ratio of growth rate, $\mu$, and carbon dioxide concentration, $\left[\mathrm{CO}_{2}\right]$ ) and $\varepsilon_{\mathrm{p}}$ (Francois et al. 1993, Laws et al. 1995) which is contradicted by some observations (e.g. Law et al. 1997). Models that incorporate a cellular regulation of active carbon uptake neglect the effects of either growth rate or active $\mathrm{HCO}_{3}{ }^{-}$uptake on $\varepsilon_{\mathrm{p}}$ (Laws et al. 1997, Yoshioka 1997, Popp et al. 1998).

•E-mail: klkeller@princeton.edu
Based on a model interpretation, Laws et al. (1997) and Popp et al. (1998) concluded that the upward curvature of $\varepsilon_{\mathrm{p}}$ with increasing $\left.\mu / \mathrm{CO}_{2}\right]$ (i.e. an increasing positive deviation from a linear relationship) which they observed is inconsistent with $\mathrm{HCO}_{3}^{-}$uptake. However, independent experiments demonstrate $\mathrm{HCO}_{3}{ }^{-}$uptake for several of the very species they investigated (e.g. Sikes et al. 1980, Colman \& Rotadore 1995). It is important to resolve this discrepancy, since phytoplankton unable to take up $\mathrm{HCO}_{3}{ }^{-}$may be $\mathrm{CO}_{2}{ }^{-}$ limited, even if they actively transport $\mathrm{CO}_{2}$ (Riebesell et al. 1993). Here we present a simple model of phytoplankton carbon uptake and isotopic fractionation and show that existing isotope data are consistent with active $\mathrm{HCO}_{3}^{-}$uptake.

The model. To model $\varepsilon_{\mathrm{p}}$ we use an approximated carbon isotope balance of a phytoplankton cell (Francois et al. 1993), resulting in:

$$
\varepsilon_{\mathrm{p}}=\varepsilon_{\mathrm{up}}+\theta\left(\varepsilon_{\mathrm{f} \mathrm{LX}}-\varepsilon_{\text {diff }}\right)
$$

In this equation $\varepsilon_{\text {up }}, \varepsilon_{\text {fix }}$, and $\varepsilon_{\text {diff }}$ represent the fractionation effects of the carbon uptake processes, carbon fixation, and diffusive carbon loss from the cell, respectively, and $\theta$ is the ratio of cellular carbon loss to carbon influx. $\varepsilon_{\mathrm{p}}$ is well approximated by $\delta^{13} \mathrm{C}_{\mathrm{CO}_{2}}-\delta^{13} \mathrm{C}_{\mathrm{OM}}$, the difference between the isotopic compositions of the external $\mathrm{CO}_{2}$ and the organic matter pools (Goericke et al. 1994). Note that this stylized model neglects a host of potentially important cellular characteristics such as respiration or cellular compartments.

$\theta$ is a function of the diffusive $\mathrm{CO}_{2}$ influx (equal to $\left[\mathrm{CO}_{2}\right] \cdot P \cdot A$, where $P$ denotes the membrane permeability and $A$ the membrane surface area), the cellular carbon demand (equal to $\mu \cdot Q_{c}$, where $Q_{c}$ represents the cellular carbon content), as well as the active carbon uptake fluxes. To model the regulation of carbon 
uptake in the simplest way possible, we assume that the cells adjust their active carbon uptake in a constant ratio $(y)$ to their carbon fixation rate. We neglect the diffusive flux of the charged $\mathrm{HCO}_{3}{ }^{-}$molecule across the lipid cell membrane as well as the effects of the diffusive boundary layer. The ratio of carbon loss to carbon influx is then:

$$
\theta=\frac{1+(\gamma-1) \frac{\mu Q_{c}}{\left[\mathrm{CO}_{2}\right] P A}}{1+\gamma \frac{\mu Q_{\mathrm{c}}}{\left[\mathrm{CO}_{2}\right] P A}}
$$

$\varepsilon_{u p}$ is calculated by an isotopic mass balance of the carbon fluxes into the internal $\mathrm{CO}_{2}$ pool. We assume the fractionation of the carbon uptake mechanism $\left(\varepsilon_{t}\right)$ to be equal to the fractionation by diffusion $\left(\varepsilon_{\mathrm{t}}=\varepsilon_{\text {diff }}=\right.$ $0.7 \%$; O'Leary 1984). Because we assume zero $\mathrm{HCO}_{3}{ }^{-}$ efflux, all the $\mathrm{HCO}_{3}{ }^{-}$actively taken up has to be completely converted into $\mathrm{CO}_{2}$. In this situation, the intracellular dehydration shows no isotopic fractionation. Finally, in the case of active $\mathrm{HCO}_{3}^{-}$uptake, the substrate for the carbon uptake mechanism has an isotopic composition $\left(\delta^{13} \mathrm{C}_{\text {source }}\right)$ which is around $9 \%$ higher than $\delta^{13} \mathrm{C}_{\mathrm{CO}_{2}}$ (Mook et al. 1974), $\varepsilon_{\mathrm{up}}$ is then:

$$
\varepsilon_{\mathrm{up}}=\varepsilon_{\mathrm{t}}+\frac{\gamma}{\frac{\left[\mathrm{CO}_{2}\right] P A}{\mu Q_{\mathrm{c}}}+\gamma}\left(\delta^{13} \mathrm{C}_{\mathrm{CO}_{2}}-\delta^{13} \mathrm{C}_{\text {saurce }}\right)
$$

and $\varepsilon_{\mathrm{p}}$ becomes:

$$
\begin{aligned}
\varepsilon_{\mathrm{p}}= & \varepsilon_{\mathrm{t}}+\frac{\gamma}{\frac{\left.\mathrm{CO}_{2}\right] \mathrm{PA}^{p}}{\mu Q_{\mathrm{c}}}+\gamma}\left(\delta^{13} \mathrm{C}_{\mathrm{CO}_{2}}-\delta^{13} \mathrm{C}_{\text {source }}\right) \\
+ & \frac{1+(\gamma-1) \frac{\mu Q_{c}}{\left[\mathrm{CO}_{2}\right] P A}}{1+\gamma \frac{\mu Q_{c}}{\left[\mathrm{CO}_{2}\right] P A}}\left(\varepsilon_{\mathrm{f} 1 \mathrm{x}}-\varepsilon_{\mathrm{diff}}\right)
\end{aligned}
$$

For pure diffusive $\mathrm{CO}_{2}$ uptake (i.e. $\gamma=0$ ) this reduces to the model proposed by Francois et al. (1993) (and to a simplified version of the model of Rau et al. 1996), which both predict $\varepsilon_{p}$ to be a linear function of the variable $\mu /\left(\left.\mathrm{CO}_{2}\right|^{\text {. }}\right.$. The variable $\left.4 / \mathrm{CO}_{2}\right]$, which is proportional to the ratio of carbon demand to maximum diffusive $\mathrm{CO}_{2}$ influx, effectively quantifies the extent of deficiency of diffusive $\mathrm{CO}_{2}$ supply for the photosynthetic carbon demand.

We use this model to analyze published data for the microalgae Phaeodactylum tricornutum, Porosira glacialis, and Emiliania huxleyi, and the cyanobacterium Synechococcus sp. Our model is capable of fitting other isotope data as well (e.g. Fielding et al. 1998, results not shown) and the discussed data sets are chosen to represent a wide variety of phytoplankton species. To estimate the model parameters, we vary them within rea- sonable ranges to minimize the mean square model error of $\delta^{13} \mathrm{C}_{\mathrm{OM}}$ (Table 1). For this study, we assume $\mathrm{HCO}_{3}{ }^{-}$as substrate for the carbon uptake mechanism (although the model can of course account for active $\mathrm{CO}_{2}$ uptake). To simplify the discussion, we express the observations and the model results as $\delta^{13} \mathrm{COM}_{\mathrm{O}}$. normalized to a $\delta^{13} \mathrm{C}_{\mathrm{CO}_{2}}$ of $-7.5 \%$ and a $\delta^{13} \mathrm{C}_{\mathrm{HCO}_{3}^{-}}$of $+1.5 \%$ (representative of seawater at $15^{\circ} \mathrm{C}$; Mook et al. 1974. Goericke 1994).

Results. The model fits (Fig. 1) demonstrate that the model is able to represent the main features of the data rather well. The membrane permeabilities of the microalgae are relatively high (varying between 1.1 and $3.3 \times 10^{-5} \mathrm{~ms}^{-1}$ ) while the ratios of active $\mathrm{HCO}_{3}^{-}$ uptake to carbon fixation are relatively low (between 0 and 2.3). The $P$. glacialis data are best described in our model with no active $\mathrm{HCO}_{3}^{-}$uptake (e.g. $\gamma=0$ ). This may be reasonable, given the low growth rates for $P$. glacialis that range between 0.09 and $0.32 \mathrm{~d}^{-1}$. Alternative explanations cannot be excluded, however, such as a different regulation of active carbon uptake than assumed in our model.

For the microalgae (i.e. all the species except Synechococcus sp.), $\delta^{13} \mathrm{C}_{\mathrm{OM}}$ increases significantly with $\left.\mu / \mathrm{CO}_{2}\right\}$. At very low $\left.\mu / \mathrm{CO}_{2}\right]$ values, the diffusive $\mathrm{CO}_{2}$ exchange fluxes across the membrane are large compared to the carbon fixation and active carbon uptake fluxes. In this situation, the preference for ${ }^{12} \mathrm{CO}_{2}$ by carbon fixation does not significantly affect the isotopic composition of the internal $\mathrm{CO}_{2}$ pool, because the gross $\mathrm{CO}_{2}$ fluxes keep the internal and external $\mathrm{CO}_{2}$ pools close to isotopic equilibrium. The resulting fractionation effect of photosynthesis is close to the large fractionation by carbon fixation, and $\delta^{13} \mathrm{C}_{\mathrm{OM}}$ is low. As $\left.\mathrm{m} / \mathrm{CO}_{2}\right]$ increases, the diffusive $\mathrm{CO}_{2}$ exchange fluxes

Table 1. Model parameters, their allowed ranges, and the root mean square error (RMSE) for the model fits. We use the cell surface areas and

\begin{tabular}{|c|c|c|c|c|}
\hline $\begin{array}{l}\text { Parameter: } \\
\text { Unit: } \\
\text { Allowed range: }\end{array}$ & $\begin{array}{c}\varepsilon_{f i x} \\
\% o \\
20-30^{a}\end{array}$ & $\begin{array}{c}P \\
\mathrm{~ms} \mathrm{~s}^{-1} \\
3 \times 10^{-8}-4 \times 10^{-3^{b}}\end{array}$ & $\begin{array}{c}\gamma \\
- \\
0-7.5^{c}\end{array}$ & $\begin{array}{c}\text { RMSE } \\
\% \\
-\end{array}$ \\
\hline E. huxleyi & 25.3 & $1.8 \times 10^{-5}$ & 2.2 & 0.63 \\
\hline P. tricornutum & 26.6 & $3.3 \times 10^{-5}$ & 2.3 & 1.2 \\
\hline P. glacialis & 23.0 & $1.1 \times 10^{-5}$ & 0.0 & 3.1 \\
\hline Synechococcus sp. & 30.0 & $3.0 \times 10^{-8}$ & 7.5 & 1.2 \\
\hline \multicolumn{5}{|c|}{$\begin{array}{l}\text { 'Adopting the range for ribulose 1,5-bisphosphate carboxylase-oxy- } \\
\text { genase (Goricke et al. 1994) and assuming neglible } \beta \text {-carboxylation } \\
{ }^{b} \text { Gutknecht et al. (1977), Salon et al. (1996) } \\
\text { cRange between pure diffusive uptake (i.e. } \gamma=0 \text { ) and the maximum } \\
\text { value in Synechococcus sp. observed by Tchernov et al. (1997) }\end{array}$} \\
\hline
\end{tabular}
cellular carbon contents given by Popp et al. (1998). $\varepsilon_{\text {fix }}$ : fractionation effect of carbon fixation; $P$ : cell membrane permeability; $\gamma$ : ratio of active carbon uptake to carbon fixation rate 


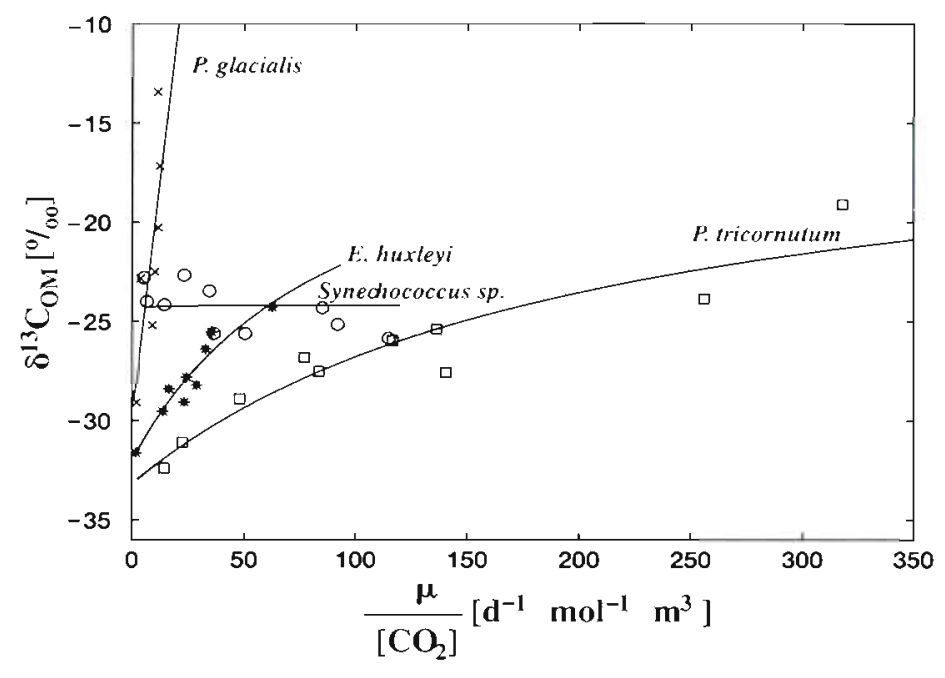

Fig. 1 Comparison of experimental data for Phaeodactylum tricornutum (ם, Laws et al. 1997), Synechococcus sp. (o, Popp et al. 1998), Emiliania huxleyi (*, Bidigare et al. 1997), and Porosira glacialis ( $x$, Popp et al. 1998) with the model fits (lines). Shown are $\delta^{13} \mathrm{C}_{\mathrm{OM}}$ data for $\mu / \mathrm{CO}_{2} \mid$ values less than $350 \mathrm{~d}^{-1} \mathrm{~mol}^{-1} \mathrm{~m}^{3}$ Model parameters and the root mean square errors of the model fits are given in Table 1

across the membrane decrease relative to the carbon fixation and active carbon uptake fluxes. As a result, the preference for ${ }^{12} \mathrm{CO}_{2}$ by carbon fixation increasingly enriches the internal carbon pool with ${ }^{13} \mathrm{CO}_{2}$, carbon fixation uses more ${ }^{13} \mathrm{CO}_{2}$, and $\delta^{13} \mathrm{C}_{\mathrm{OM}}$ increases.

For low to intermediate ${ }^{\mu} \mathrm{CCO}_{2} \mid$ values the $\delta^{13} \mathrm{C}_{\mathrm{OM}}$ data for the microalgae may be approximated by a straight line as would be predicted from a pure $\mathrm{CO}_{2}$ diffusion model, although the net $\mathrm{CO}_{2}$ diffusion flux may in fact be outwards. For example, for the species Emiliania huxleyi at $\left[\mathrm{CO}_{2}\right]=10^{-2} \mathrm{~mol} \mathrm{~m}{ }^{-3}$ and $\mu=0.5 \mathrm{~d}^{-1}$ (resulting in $\left.\mu /\left[\mathrm{CO}_{2}\right]=50 \mathrm{~d}^{-1} \mathrm{~mol}^{-1} \mathrm{~m}^{3}\right)$ the modeled active $\mathrm{HCO}_{3}^{-}$uptake flux is $8.9 \times 10^{-18} \mathrm{~mol} \mathrm{C}$ cell-1 $\mathrm{s}^{-1}$ while the net diffusion loss is $4.8 \times 10^{-18} \mathrm{~mol} \mathrm{C}$ cell $^{-1} \mathrm{~s}^{-1}$. The large diffusive $\mathrm{CO}_{2}$ exchange fluxes (in our example $1.6 \times 10^{-17} \mathrm{~mol} \mathrm{C} \mathrm{cell}{ }^{-1} \mathrm{~s}^{-1}$ inwards and $2.0 \times 10^{-17} \mathrm{~mol}$ $C$ cell $^{-1} s^{-1}$ outwards) dominate the other fluxes and largely determine the isotopic disequilibrium across the membrane. This situation is caused by the relatively high $P$ and low $\gamma$. Note that the approximately linear range of $\delta^{13} \mathrm{C}_{\mathrm{OM}}$ may sometimes be exceeded by oceanic $\mu /\left\{\mathrm{CO}_{2} \mid\right.$ values (e.g. $\left.{ }^{\mu} / \mathrm{CO}_{2}\right]=260 \mathrm{~d}^{-1}$ $\mathrm{mol}^{-1} \mathrm{~m}^{3}$ for $\left[\mathrm{CO}_{2}\right]=8 \times 10^{-3} \mathrm{~mol} \mathrm{~m} \mathrm{~m}^{-3}$ and $\mu=2.1 \mathrm{~d}^{-1}$ ) (Eppley 1972, Codispoti et al. 1982).

For the cyanobacterium Synechococcus sp., the estimated $P$ is low $\left(3 \times 10^{-8} \mathrm{~m} \mathrm{~s}^{-1}\right.$, equal to the experimental estimate of Salon et al. 1996), while $\gamma$ is high (7.5, equal to the maximum value for Synechococcus $\mathrm{sp}$. observed by Tchernov et al. 1997 at high light levels). $\varepsilon_{f_{1 x}}$ is estimated as $30 \%$. A perhaps more realistic fractionation of $21.5 \%$ cobserved for the freshwater cyanobacterium Anacystis nidulans; Guy et al. 1993) would be obtained if $\varepsilon_{\text {up }}$ were around $8 \%$, or if the cells were taking up predominantly $\mathrm{CO}_{2}$. However, as long as important model parameters like $\varepsilon_{\mathrm{up}}$ and $\varepsilon_{\mathrm{ilx}}$ for Synechococcus sp, are unknown, the isotope data seem consistent with active $\mathrm{HCO}_{3}{ }^{-}$uptake. Note that the model parameters for Synechococcus sp. are at the extremes of the imposed ranges (Table 1). Allowing, for example, a lower $P$ would slightly reduce the model error, but violate the experimental estimate of Salon et al. (1996).

$\delta^{13} \mathrm{C}_{\mathrm{OM}}$ for Synechococcus $\mathrm{sp}$. is approximately constant over the range of $\mu / \mathrm{CO}_{2} \mid$ of interest. This is explained in our model by the small $\mathrm{CO}_{2}$ exchange fluxes relative to the other fluxes, caused by the relatively low $P$ and relatively high $\gamma$. This results in an approximately constant $\theta$, and $\delta^{13} \mathrm{C}_{\mathrm{OM}}$.

Discussion. Laws et al. (1997) and Popp et al. (1998) concluded that a downward curvature of $\delta^{13} \mathrm{C}_{\mathrm{OM}}$ with increasing $\left.\mu / \mathrm{CO}_{2}\right]$ excludes active $\mathrm{HCO}_{3}{ }^{-}$uptake. In contrast, our analysis shows that the downward curvature of $\delta^{13} \mathrm{C}_{\mathrm{OM}}$ is consistent with active $\mathrm{HCO}_{3}{ }^{-}$uptake. To analyze whether $\mathrm{HCO}_{3}^{-}$or $\mathrm{CO}_{2}$ is actively taken up, Laws et al. (1997) compared the $\delta^{13} \mathrm{C}_{\mathrm{OM}}$ predicted from a linear extrapolation at low $\mathrm{H}^{-}\left[\mathrm{CO}_{2}\right]$ values with the actual measurements. A downward curvature at higher $\left.\mu_{/} / \mathrm{CO}_{2}\right]$ values indicates a decrease in $\delta^{13} \mathrm{CoM}_{\mathrm{M}}$ at higher $\gamma$. Laws et al. (1997) reasoned that active $\mathrm{HCO}_{3}{ }^{-}$ uptake would introduce a positive shift in $\delta^{13} \mathrm{C}_{\mathrm{OM}}$ and is hence inconsistent with the observed downward shift. This reasoning neglects that an increased $\gamma$ additionally increases the ratio of $\mathrm{CO}_{2}$ efflux to carbon influx (Eq. 2), relative to the linear extrapolation. This higher ratio of $\mathrm{CO}_{2}$ efflux to carbon influx acts to decrease $\delta^{13} \mathrm{C}_{\mathrm{OM}}$ and explains the observed downward curvature-even in the case of active $\mathrm{HCO}_{3}$ - uptake. In fact, assuming $\mathrm{CO}_{2}$ instead of $\mathrm{HCO}_{3}^{-}$as substrate for the carbon uptake mechanism (i.e. $\delta^{13} \mathrm{C}_{\text {source }}=-7.5 \%$ ) results in different calibration parameters, but indistinguishable model fits. Experimental data indicate that both $\mathrm{HCO}_{3}^{-}$and $\mathrm{CO}_{2}$ are possible substrates for the carbon uptake mechanism (e.g. Salon et al. 1996, Tchernov et al. 1997). Our results illustrate that the shape of the discussed $\delta^{13} \mathrm{C}_{\mathrm{OM}}$ data as a function of $\left.\mu / \mathrm{CO}_{2}\right]$ is a poor indicator of the carbon species entering the cell.

In conclusion, the discussed isotope data can be described adequately by a simple and plausible model that represents the regulation of active carbon uptake with a single parameter. Neither an approximately linear relationship between $\left.{ }^{\mu /} / \mathrm{CO}_{2}\right]$ and $\varepsilon_{\mathrm{p}}$ nor an upward curvature of $\varepsilon_{\mathrm{p}}$ with $\mu / \mathrm{CO}_{2} \mid$ can exclude active $\mathrm{HCO}_{3}^{-}$or $\mathrm{CO}_{2}$ uptake. Whether $\mathrm{HCO}_{3}^{-}$or $\mathrm{CO}_{2}$ is actively taken up by a particular microalgae cannot presently be decided on the basis of isotope data lexcept for the case when $\delta^{13} C_{O M}$ is higher than 
$\delta^{13} \mathrm{C}_{\mathrm{CO}_{2}}$ indicating that $\mathrm{HCO}_{3}^{-}$is a significant carbon source). Available models of carbon isotopic fractionation are insufficiently constrained to distinguish between these possibilities.

Acknowledgements. We are grateful to G. H. Rau and P. D. Tortell for helpful discussions.

\section{LITERATURE CITED}

Bidigare RR, Fluegge A, Freeman KH, Hanson KL, Hayes JM, Hollander D, Jasper JP, King LL, Laws EA, Milder J, Millero FJ, Pancost R, Popp BN, Steinberg PA, Wakeham SG (1997) Consistent fractionation of ${ }^{13} \mathrm{C}$ in nature and in the laboratory: growth-rate effects in some haptophyte algae. Global Biogeochem Cycles 11:279-292

Codispoti LA, Friederich GE, Iverson RI, Hood DW (1982) Temporal changes in the inorganic carbon system of the south-eastern Bering sea during spring 1980. Nature 296: $242-245$

Colman B, Rotatore C (1995) Photosynthetic inorganic carbon uptake and accumulation in two marine diatoms. Plant Cell Environ 18:919-924

Eppley RW (1972) Temperature and phytoplankton growth in the sea. Fish Bull 70:1063-1085

Fielding AS, Turpin DH, Guy RG, Calvert SE, Crawford DW, Harrison PJ (1998) Influence of the carbon concentrating mechanism on carbon stable isotope discrimination by the marine diatom Thalassiosira pseudonana. Can J Bot 76: 1098-1103

Francois R, Altabet MA, Goericke R, McCorkle DC, Brunet C, Poisson A (1993) Changes in the $\delta^{13} \mathrm{C}$ of surface water particulate organic matter across the subtropical convergence in the SW Indian Ocean. Global Biogeochem Cycles $7: 627-644$

Goericke R, Montoya JP, Fry B (1994) Physiology of isotopic fractionation in algae and cyanobacteria. In: Lajtha $K$, Michner RH (eds) Stable isotopes in ecology and environmental science. Blackwell Scientific Publishing, Oxford, p $187-221$

Gutknecht J, Bisson MA, Tosteson FC (1977) Diffusion of carbon dioxide through lipid bilayer membranes. J Gen Physiol 69:779-794

Guy RD, Fogel ML, Berry JA (1993) Photosynthetic fractiona-

Editorial responsibility: Otto Kinne (Editor),

Oldendorf/Luhe, Germany tion of the stable isotopes of oxygen and carbon. Plant Physiol 101:37-47

Jasper JP, Hayes JM (1990) A carbon isotope record of $\mathrm{CO}_{2}$ levels during the late Quaternary. Nature 374:462-464

Laws EA, Popp BN, Bidigare RR, Kennicut MC, Macko SA (1995) Dependence of phytoplankton carbon isotopic composition on growth rate and $\left[\mathrm{CO}_{2}\right]_{d q}$ : theoretical considerations and experimental results. Geochim Cosmochim Acta 59:1131-1138

Laws EA, Bidiggare RR, Popp BN (1997) Effect of growth rate and $\mathrm{CO}_{2}$ concentration on carbon isotopic fractionation by the marine diatom Phaeodactylum tricornutum. Limnol Oceanogr 42:1552-1560

Mook WG, Bommerson JC, Staverman WH (1974) Carbon isotope fractionation between dissolved bicarbonate and gaseous carbon dioxide. Earth Planet Sci Lett 22:169-176

O'Leary MH (1984) Measurement of the isotope fractionation associated with diffusion of carbon dioxide in aqueous solution. J Phys Chem 88:823-825

Popp BN, Laws EA, Bidigare RR, Dore JE, Hanson KL, Wakeham SG (1998) Effect of phytoplankton cell geometry on carbon isotopic fractionation. Geochim Cosmochim Acta 62:69-77

Rau GH, Riebesell U, Wolf-Gladrow D (1996) A model of photosynthetic ${ }^{13} \mathrm{C}$ fractionation by marine phytoplankton based on diffusive molecular $\mathrm{CO}_{2}$ uptake. Mar Ecol Prog Ser 133:275-285

Raven JA (1997) Inorganic carbon acquisition by marine autotrophs. Adv Bot Res 27:86-209

Riebesell U, Wolf-Gladrow DA, Smetacek V (1993) Carbon dioxide limitation of marine phytoplankton growth rates. Nature 361:249-251

Salon C, Mir NA, Canvin DT (1996) Influx and efflux of inorganic carbon in Synechococcus UTEX 625. Plant Cell Environ 19:247-259

Sikes CS, Roer RD, Wilbur KM (1980) Photosynthesis and coccolith formation: inorganic carbon sources and net inorganic reaction of deposition. Limnol Oceanogr 25:248-261

Tchernov D, Hassidim M, Luz B, Sukenik A, Reinhold L, Kaplan A (1997) Sustained net $\mathrm{CO}_{2}$ evolution during photosynthesis by marine microorganisms. Curr Biol 7 : $723-728$

Tortell PD, Reinfelder JR, Morel FMM (1997) Active uptake of bicarbonate by diatoms. Nature 390:243-244

Yoshioka T (1997) Phytoplanktonic carbon isotope fractionation: equations accounting for $\mathrm{CO}_{2}$-concentrating mechanisms. J Plankton Res 19:1455-1476

Submitted: December 23, 1998; Accepted: April 20, 1999 Proofs received from author(s): May 18, 1999 